\title{
Modelling and predicting growth of psychrotolerant pseudomonads in milk and cottage cheese
}

Martinez Rios, Veronica; Østergaard, Nina Bjerre; Rosshaug, Per Sand; Dalgaard, Paw

Publication date:

2015

Document Version

Peer reviewed version

Link back to DTU Orbit

Citation (APA):

Martinez Rios, V., Østergaard, N. B., Rosshaug, P. S., \& Dalgaard, P. (2015). Modelling and predicting growth of psychrotolerant pseudomonads in milk and cottage cheese. Abstract from 9th International Conference on Predictive Modelling in Food, Rio de Janeiro, Brazil.

\section{General rights}

Copyright and moral rights for the publications made accessible in the public portal are retained by the authors and/or other copyright owners and it is a condition of accessing publications that users recognise and abide by the legal requirements associated with these rights.

- Users may download and print one copy of any publication from the public portal for the purpose of private study or research.

- You may not further distribute the material or use it for any profit-making activity or commercial gain

- You may freely distribute the URL identifying the publication in the public portal 
Title:

Modelling and predicting growth of psychrotolerant pseudomonads in milk and cottage cheese

Authors \& affiliations:

Veronica Martinez-Rios, Nina Bjerre Østergaard, Per Sand Rosshaug, Paw Dalgaard

National Food Institute (DTU Food), Technical University of Denmark, Kgs. Lyngby, Denmark, pada@food.dtu.dk

Abstract: (Your abstract must use Normal style and must fit in this box. Your abstract should be no longer than 300 words. The box will 'expand' over 2 pages as you add text/diagrams into it.)

Mathematical models were developed and evaluated for growth of psychrotolerant pseudomonads in chilled milk and cottage cheese with cultured cream dressing. The mathematical models include the effect of temperature, $\mathrm{pH}, \mathrm{NaCl}$, lactic acid and sorbic acid. A simplified cardinal parameter growth model was developed based on growth in broth. Subsequently, the reference growth rate parameter $\left(\mu_{\text {ref }}\right.$ at $\left.25^{\circ} \mathrm{C}\right)$ was fitted to a total of 35 growth rates from cottage cheese with cultured cream dressing. Growth rate models for milk and cottage cheese were evaluated by comparison with data from literature and new experiments. Growth of psychrotolerant pseudomonads in heat-treated milk resulted in a bias factor $\left(B_{f}\right)$ of 1.08 and an accuracy factor $\left(A_{f}\right)$ of 1.32 , whereas the calibrated model for growth rates in cottage cheese with cultured cream dressing and in raw milk resulted in $B_{f}$ of 1.08 and $A_{f}$ of 1.43. The acceptable simulation zone method showed the new model for cottage cheese to successfully predict growth of psychrotolerant pseudomonads at both constant and dynamic temperature storage conditions. The new models can be used together with the Food Spoilage and Safety Predictor (FSSP) software to predict growth of psychrotolerant pseudomonads and shelf-life of chilled cottage cheese and of milk at constant and dynamic storage temperatures. The developed models and the applied methodology is likely to be applicable for shelf-life assessment of other types of fermented or unripened dairy products as well as other products where psychrotolerant pseudomonads are important for spoilage. 